\title{
LOS ALICANTINOS EN LA ARGELIA FRANCESA (1830-1914)
}

\author{
Juan Bta. Vilar \\ Universidad de Alicante
}

\section{1. - EL CICLO OCHOCENTISTA DE LAS MIGRACIONES ESPAÑOLAS A ARGELIA}

Aspecto poco conocido de nuestra proyección exterior contemporánea es la presencia española en la Argelia francesa. De su importancia baste decir que el elemento hispánico ocupó el segundo lugar en el conjunto del poblamiento europeo de la colonia y predominó de forma absoluta en la Oranie durante todo el siglo XIX.

En tanto Francia vacilaba sin acertar con el régimen colonial idóneo para Argelia, cuya ocupación fue iniciada en 1830, los españoles, impulsados por propia iniciativa y sin ayuda oficial alguna, colonizaron eficazmente amplios sectores del país. Al tomar cuerpo una emigración francesa estatalmente dirigida, nuestros compatriotas mediterráneos, $y$ en menor medida los italianos y malteses, se hallaban asentados firmemente en Argelia.

La espontánea emigración española había hecho ascender en 1841 a 9.748 el número de sus colonos en Argelia, frente a los 11.322 franceses

* Conferencia pronunciada el dia 20 de noviembre de 1981 en la Casa de la Cultura de Alicante, como clausura de la Semana de Historia Arabe de Alicante, organizada por el expresado organismo en colaboración con la Excma. Diputación Provincial, Caja de Ahorros Provincial de la misma ciudad, Departamento de Historia Medieval y Arabe de la Universidad alicantina e Instituto Egipcio de Estudios Islámicos de Madrid. 
atraídos por todos los procedimientos imaginables. Un bienio más tarde, siempre según estadísticas oficiales, en Orán vivían 6.025 españoles y 1.741 ciudadanos franceses.

Los progresos de la penetración ibérica prosiguieron a rítmo acelerado. De los 181.000 extranjeros residentes en Argelia en 1881, eran españoles 114.320, número incrementado en 30.000 en los cinco años siguientes. No obstante el carácter asimilacionista de la legislación franco-argelina, en particular a partir de la ley de nacionalización automática de 1889, la colonia española alcanzó en 1900 las 160.000 unidades. La extranjera más numerosa (1).

En años sucesivos sus efectivos tenderán a disminuir, al gravitar sobre ella el doble efecto negativo de una inmigración española decreciente y una presión francesa de día en día más irresistible. Los cambios de nacionalidad y el retorno de residentes, en ocasiones masivo, generará el definitivo cambio de signo migratorio, anunciado desde los años de 1880 en que pasó a un primer plano el éxodo a lberoamérica.

Los sucesos de Saida de 1881, en que un centenar largo de indefensos jornaleros españoles - oriundos en parte de la provincia de Alicante - perecieron a manos de los nacionalistas argelinos, sorprendidos cuando trabajaban en los atochales oraneses, y los abusos cometidos por los empresarios de la colonia y sus agentes reclutadores con unos emigrantes analfabetos y desprovistos de protección consular, impulsaron al gobierno a disponer -6 de mayo 1882 - que en adelante el Instituto Geográfico y Estadístico incluyera en sus censos relación pormenorizada de la emigración exterior.

De la relevancia cuantitativa del movimiento migratorio hacia Argelia dará idea el hecho de que en 1885 representase el 39,55 por cien del total de la emigración exterior española. Esa proporción, con alternativas de signo vario, decreció en años posteriores. Pero no por contracción de cifras absolutas, sino por el excepcional y paralelo incremento de la emigración a la América latina. República Argentina, Cuba, Brasil y Uruguay principalmente.

Es de notar que en el trienio de 1882-1884, primero sobre el que se poseen series completas, recientes todavía los acontecimientos de Saida, el número de entradas en España desde Argelia supera a las salidas en unas 6.500 unidades. El movimiento cambiará de signo un año más tarde - exceso de 2.287 salidas sobre retornos - una vez pacificado el sur oranés. En adelante la corriente migratoria se establizará en un punto

(1) J.B. VILAR. Emigración española a Argelia (1830-1900). Colonización hispánica de la Argelia francesa. Inst. de Est. Africanos en Madrid. 1975, p.3. 
de equilibrio, o bien registrará saldos favorables para Argelia escasamente por encima del millar de unidades.

Los años de 1893 - 1895 y 1898 fueron de incuestionable dominio de los retornos. La adversa coyuntura económica argelina finisecular es determinante, pero también las drásticas disposiciones asimilacionistas contenidas en la ley de 1889 que, en Argelia igual que en Francia (2), pretendía contrarrestar el marcado declive demográfico francés con la absorción de los residentes de origen europeo. Factores generadores del cambio fueron, a su vez, la reactivación económica española coincidiendo con la liquidación de nuestros gravosos compromisos coloniales en el Caribe y Filipinas, y con la repatriación de capitales desde Ultramar, a donde para entonces prefería marchar el emigrante alicantino, murciano y almeriense, inclinados hasta entonces por Argelia.

En los últimos veinte años del siglo los retornos desde la colonia francesa predominan ligeramente sobre las salidas, con un saldo negativo de 8.504 unidades (3). Esa tendencia se acentuaría en los primeros años de la actual centuria - exceso de 3.895 retornos sobre salidas en el período 1900 - 1907 (4) - y de 11.715 unidades para toda la fase 1900 1914 (5), año este último que culmina con la repatriación masiva de emigrantes españoles que acompañó a la beligerancia francesa en la primera conflagración mundial.

Cabe puntualizar que las estadísticas españolas sobre emigración a Argelia son en extremo imprecisas para la fase ochocentista. Se trata de evaluaciones aproximativas por debajo de las cifras reales. No recogen los datos correspondientes a una cuantiosa emigración clandestina, ni computan las emigraciones políticas, como tampoco las entradas en la colonia de nuestros conciudadanos desde puertos no españoles.

\section{2. - ALICANTE, PROVINCIA DE EMIGRACION}

Alicante se nos muestra en el siglo XIX como la más caracterizada provincia española de emigración a Argelia.

(2) Vid. J. RUBIO, La emigración españoia a Francia. Barcelona 1974, ps. 48-74, 89114. El contexto general del fenómeno apuntado puede verse en J. BEAUJEU - GARNIER, La populatión française. Paris 1869; A. ARMENGAUD, La populatión française au $X X$ siècle. Paris. 1970; J. GARCIA FERNANDEZ, La emigración exterior de España. Barcelona. 1965.

(3) VILAR, Emigración española a Argelia... p. 480.

(4) VILAR, Crisis hispano-francesa de 1904-1907 en Argelia. Su incidencia sobre la emigración peninsular, la cuestión marroquí y el proceso de aproximación francoespañola. Awraq, núm. 1 (Madrid, 1978), p. 88.

(5) VILAR, Los españoles en la Argelia francesa (1830-1914). Prologo de J.M. Jover Zamora. Publ. Ministerio de Asuntos Exteriores. Madrid, 1982, En prensa. 
Situada en mitad del flanco sureste de la Península Ibérica, sin embargo su territorio queda fuera del área típicamente latifundista de la España árida. Predomina aquí la mediana y pequeña propiedad, sobre todo en los espacios dedicados al regadío. En ellos, las grandes propiedades, cuando se dan, aparecen parcelizadas para su explotación en régimen de colonaje, aparcería o arriendo. Pero una parte importante del secano no escapa a los factores negativos propios de los latifundios andaluces, extremeños y manchegos. En particular, la descapitalización, el absentismo, el aprovechamiento extensivo, el atraso técnico, los bajos rendimientos y la mano de obra estacional.

La tendencia al minifundio y la dispersión parcelaria (6) fueron, acaso, los principales obstáculos al progreso agrario en los regadios alicantinos. Los abnegados labradores, alejados del bullicio de la ciudad, vivían en la huerta a la sombra de sus barracas, consagrados por entero al cuidado de hortalizas y frutales. Sabían sacar partido de todo y obtenían un saneado ingreso adicional con la seda y el cáñamo, que para el hortelano de Orihuela, Callosa y Elche representa lo que la almendra y la uva para sus colegas de la Marina y de las comarcas interiores de la provincia. Sólo así les era factible pagar el urento» al propietario, satisfacer con puntualidad la contribución - evitando al «apremio» o recargo de un cuarto por real $-y$ disponer de liquidez para afrontar algún gasto no alimentario - ropas y enseres principalmente - y para afrontar enfermedades y otros imprevistos. Pero la vida en la huerta era malsana, el trabajo agotador y la muerte rondaba siempre en torno a unas barracas de barro y cañizo, cuyo aspecto misérrimo - dejando a un lado lirismos folklóricos - causaba penosa impresión en los viajeros.

Más infortunado era todavía el bracero, reducido a vivir de un jornal parco e inseguro, y sin otra opción en momentos de crisis que perecer de hambre o emigrar. «En el año próximo pasado - subraya en 1846 el capitán general de Valencia en cierto informe referido a los de Alicante y su término (7) - ni aún les ha sido posible practicar la sementera por falta de aguas pluviales. En tan dura situación no es dudosa ni extraña la determinación que aquellos infelices habitantes han tomado en la triste alternativa de perecer de hambre con sus familias o de emigrar pasando a las vecinas costas de Africa, donde se les brindan (oportunidades) con pingües jornales y aún con tierras de cultivo en propiedad mediante un módico canon anual».

(6) Vid. F. CABALLERO. Memoria sobre el fomento de la población rural. Madrid, 1863, p. 40 ss.

(7) Apéndice I. 
El drenaje migratorio, que hasta el momento había incidido especialmente sobre la huerta alicantina, no tardó en alcanzar a localidades y lugares ubicados en el secano, tales como Muchamiel, San Juan, Benimagrell, Santa Faz, Villafranqueza y San Vicente de Raspeig. También a los grandes pueblos del interior, entre Monforte y el valle de Elda.

El nivel de vida era aquí uno de los más bajos de España. Se comprende el estancamiento demográfico de ciertas área específicamente agrícolas durante el XIX, en tanto los sectores urbanos industrializados o en vías de industrialización -en particular las ciudades de Alcoy y Alicante - conocían un sustantivo incremento en función del éxodo rural.

Las series conocidas de precios y salarios, aunque bastante incompletas, evidencian el escaso poder adquisitivo de las clases populares (8). A mediados de siglo la dieta elimentaria alicantina resultaba bastante incompleta. "La comida ordinaria de los labradores en todos los pueblos y distritos rurales - apunta Roca de Togares en $1848(9)$ - es pan de cebada o de maíz, cebollas, ajos, pimientos y tomates crudos, una sardina el día en que caban o hacen faena pesada, y los domingos y alguna noche en la semana, ensalada de nabo, col, acelga, etc., cocida».

Faltaban alimentos tan básicos como son el pan de trigo, la carne, la leche, los huevos y la fruta. Dieta precaria que recuerda bastante a la coetánea de Murcia (10), aventajaba sin embargo, al menú cotidiano del jornalero de Almería, donde la base del alimento - reza un informe municipal (11) - son las gachas-migas y gachas con caldo confeccionadas ambas con harina de maíz».

Hacia 1895, durante la etapa isabelina precedente a la depresión final del reinado, Alicante figura entre el grupo de provincias con superior nivel salarial. Según J. Nadal (12), el jornal medio del peón de carreteras

(8) Compárese con el paralelo caso murciano. Vid. J.B. VILAR, Bases socjales y económicas del Cantón murciano. $2^{\mathrm{a}}$ ed. Madrid, 1976 ps. 73 - 90.

(9) Cfr. R. de ALTAMIRA Y CREVEA, Derecho consuetudinario y economia popular en la provincia de Alicante. Madrid. 1905, p. 49.

(10) VILAR, Migraciones murcianas a Argelia en el siglo XIX: su impacto demográfico, social y económico sobre la provincia de origen. Cuadernos de Historia (Anexo de Hispania dedicado a Murcial, Madrid, 1982. En prensa.

(11) VILAR, Emigración almeriense a Argelia en el siglo XIX: sus repercusiones politicas, sociales y económicas sobre la provincia de origen. Actas del I Congreso de Historia de Andalucia, vol. "Andalucia Contemporánea», t. II (Córdoba, 1979) p.243. Vid. también P. CONARD, A. LOVETT, Problémes de l'evaluation du coût de la vie en Espagne. I. Le prix dupain de XIXe siècle: une source nouvelle. Melanges de la Casa de Velazquez, $V(1969)$ ps. 414-415.

(12) La población española. Barcelona 1971 p. 169. 
en el año apuntado fue de 6,25 reales de vellón. Alicante y Murcia figuran entre las nueve de salario más alto con 7,5 y 7 respectivamente. Almería, la otra provincia de emigración a Argelia, con sus cinco reales, queda muy por debajo de la media nacional. Cabe atribuirlo a la pobreza almeriense, acentuada con la decadencia de sus minas, asi como al desfase entre producción y consumo. Las otras dos provincias, relativamente ricas y con mayores opciones de empleo, acusaban menos los efectos de las cíclicas crisis de subsistencia.

Un coetáneo (13) nos ofrece por entonces una panorámica, no por general menos válida: «... hay provincias en que la miseria y falta de trabajo ha hecho emigrar a Argelia una cuarta parte de sus habitantes (...); en otras, labradores medianamente acomodados no hace años, han cerrado sus heredades y ganan un miserable jornal en heredades ajenas para que sus familias no se mueran de hambre (...). No hay caminos, no hay pósitos, no hay bancos agrícolas, no hay beneficencia, no hay na$\mathrm{da}$, en fin, que pueda contener a los pueblos, sobrando en cambio, las rencillas de los partidos, las tropelias de las autoridades, las elecciones sin elección, el exceso de contribuciones...n. Sobre este cuadro sombrío insistirá después J. Costa (14) con referencias próximas al caso que nos ocupa.

Las fluctuaciones salariales no eran un mal exclusivo de ambientes urbanos (15), y mineros (16), ni dependian únicamente del grado de especialización del operario. En 1881 vemos a la Junta Provincial de Agricultura, Industria y Comercio de Alicante emitir un interesante dictamen (17) en respuesta a cierto interrogatorio gubernativo (18) sobre la conveniencia de establecer bancos agrícolas que desterrasen las prácticas usurarias que constreñian a los infortunados labriegos.

«El jornal de los braceros - apunta el informe (19) - varia considerablemente entre unas $y$ otras localidades de esta provincia, entre unas y otras épocas dentro de una misma localidad, y entre unos y otros años

(13) Cfr. J.L.COMELLAS, Los moderados en el poder (1844-1855). Madrid. 1970, ps. 334-335.

(14) Oligarquía y caciquismo como forma actual de gobierno en España. Urgencia y modo de cambiarla. Madrid, 1901, ps. 8-14, 23-23.

(15) Vid. VILAR, Bases sociales y económicas... Op. cit.

(16) J.B. VILAR, P. EGEA BRUMO, Mineria y sociedad en Cartagena y su distrito durante el Sexenio democrático (1868-1874). Hispania (Madrid, 1982). En prensa.

(17) ADa, Dictamen emitido por la Junta Provincial de Agricultura, Industria y Comercio de Alicante en respuesta al interrogatorio sobre creación de Bancos Agrícolas. 1881, 2 his.

(18) Gaceta de Madrid, 18 enero 1881.

(19) ADa, Dictamen... Op. cit. 
según el resultado de las cosechas. Así vemos que simultáneamente se pagan a veces cinco pesetas de jornal a los segadores de cáñamo de Orihuela, mientras en otros pueblos sólo ganan los braceros una peseta y veinticinco céntimos».

Al término del reinado de Isabel II, Alicante y su provincia, sin otra excepción válida que Alcoy, permanece marginada del proceso industrializador centrado ya por entonces en Cataluña y provincias cantábricas. Nada restaba de la incipiente industrialización del sureste peninsular en los años 40 y 50 a la sombra del "boom» minero y de factores coyunturales tales como la localización de la guerra carlista en la mitad septentrional de la Península (20).

El incremento de la producción se hizo a costa del retroceso estructural de la propiedad agraria bajo el impacto de las desamortizaciones - sobre todo la civil- $y$, en definitiva, del empeoramiento de la situación del campesinado. El rápido incremento demográfico, la pobreza de las tierras, el atraso técnico (21), la sequía..., fueron poderosos estímulos para la emigración a Argelia en la fase isabelina.

En octubre de 1845 el municipio ilicitano elevará a la intendencia provincial una exposición (22) sobre un aflictivo estado económico, agravado por unas contribuciones ajustadas al censo de 1783, y no al momento presente, y muy debajo en cuanto a población y riqueza. La sequía y los impuestos habían ocasionado en poco tiempo «la emigración de más de quinientas familias», de forma que el pueblo ofrecía un aspecto desolador con sus casas vacías y sus campos abandonados, ante la indiferencia de unos funcionarios rutinarios, exigentes y sólo atentos a su medro personal.

En años sucesivos veremos reiterar con tono lastimero iguales súplicas en pro de la exención, siquiera parcial, de las prestaciones tributarias de la ruinosa villa, habida cuenta de la extremada miseria suscitada por una sequía pertinaz. No quedando otra alternativa que la emigración para escapar al hambre, entre mayo de 1849 y junio del año-siguiente fueron expedidos 2.839 pasaportes para el interior, pavorosa cifra incrementada con otros 143 para el extranjero (23).

(20) El mejor estudio especifico es el de J. NADAL, Iridustrialización y desindustrialización en el Sureste español, 1817-1913. Moneda y Crédito, 120 (Madrid, 1972), ps. 3-80. Vid. el fenómeno en el contexto general de la economía isabelina en J.B. VILAR, Economia española del periodo isabelino. en t. XIV (La España liberal y romántica: 18331868), en "Historia General de España y América» Ed. Rialp. En prensa.

(21) Sobre este punto se han publicado ultimamente varios excelentes estudios. En particular los de A. GIL OLCINA y A. LOPEZ GOMEZ.

(22) AME, A.C. 30 octubre 1845.

(23) A. RAMOS FOLQUES, Historia de Elche. Elche, 1970 ps. 232-233. 
La hoy expansiva metrópoli survalenciana no acabó de levantar cabeza en los años isabelinos. "Hace catorce meses poco más o menos - se lamentan los regidores municipales en $1861(24)$ - que la Divina providencia ocultó su protectora mano para la infortunada villa de Elche, y por consecuencia ha traído la emigración de un gran número de habitantes, partiendo unos para los suelos africanos y otros para el de España, sólo con el interés de proporcionarse su alimento y el de sus familias....). Estimaban que en los últimos meses se habían dado de baja en el municipio unas 1.300 personas.

Del análisis de los datos publicados por A. Ramos Folqués (25), se infiere el estancamiento del censo ilicitano durante gran parte del reinado de Isabel II. En 1840 arroja una cifra de 18.042 habitantes, reducida dos años más tarde a 18.007 y en 1850 a 15.669 , es decir 3.614 vecinos, de los cuales 2.382 en el casco urbano y el resto en el término. Todavía en 1860 la población en su conjunto no pasaba de 18.734 habitantes, aproximadamente igual que veinte años antes. Sabían leer y escribir 1.837; solamente leer, 281 , y 16.626 eran analfabetos. La clase jornalera configuraba una buena mitad del censo, en tanto el resto estaba formado mayoritariamente por labradores a rento y artesanos. El estrato más ínfimo de la pirámide social desfila a nuestra vista en tétrica comparsa: 575 pobres de solemnidad, 107 ciegos y una veintena de sordomudos.

Pese a todo en Elche eran más afortunados que en otros misérrimos municipios de la provincia. El cuadro ofrecido por los secanos de Novelda y Monóvar, de Ibi, Aspe, Sax o Pinoso, e incluso de la "Foia» de Jijona, en verdad se mostraba descorazonador (26).

En la no lejana comarca litoral de la Marina el panorama no resultaba más halagüeño, aún cuando en tiempos mejores el sobrante laboral tendía a ser absorbido por la siempre pujante actividad pesquera y por la

(24) AME, A.C., 28 mayo 1861.

(25) RAMOS FOLQUES, p. 244.

(26) Abundante material al respecto en diferentes monografias regionales, subregionales y locales de alcalce y valor desiguales. Vid., verbigracia: F. ALMELA y VIVES Valencia y su reino. Valencia, 1965; P. DEFFONTAINES y M. DURLIAT, La España del Este, Cataluña, Valencia, Baleares. Barcelona, 1968, F. FIGUERAS PACHECO, Compendio histórico de Alicante. Alicante 1957; J. FUSTER, El pais Valenciano. Barcelona, 1962; J. GOMARA DALLO, Estudio demográfico de la industria en Elche. Alicante 1958; F. MARTINEZ, Coses tipiques de la Marina, la meua comarsa. Valencia, 1970; F. MARTINEZ OROZCO, Altea. Madrid, 1961; J. PASTOR DE LA ROCA, Historia general de Alicante. Alicante, 1854; V. RAMOS, Historia de la provincia de Alicante y de su capital. Alicante, 1971; RAMOS, Crónica de la provincia de Alicante. Alicante. 1979, vol. I lúnico publicadol; SALAS CAÑELLAS, Crónicas de la villa de Novelda, Novelda, 1977-1979, 2 vols; G. VIDAL Alicante ochocentista. Alicante, 1967; J.B. VILAR. Orihuela contemporánea. Murcia 1982, 3 vols (en prensa). 
navegación de cabotaje. La excesiva división de la propiedad en arriendos y subarriendos, insuficientes para proporcionar lo indispensable a una familia, al menor contratiempo arrojaba a los colonos - y no digamos a los jornaleros - en brazos de la miseria más completa.

En medio de tantas privaciones no sufría en un ápice la honorabilidad innata del labriego alicantino; "...estos proletarios - pondera Roca de Togares (27) a mediados de siglo refiriéndose a los de Campello-, si en medio de la miseria salvaje en que viven invaden a hurtadillas la propiedad rural para comer frutos, respetan la casa del acomodado y el bolsillo del transeunte...) Añade que entre los 400 vecinos del distrito ni uno sólo, por desesperada que fuera su situación, y pese a ocasionales infracciones de la ley, podian ser considerados maleantes y vagos habituales. Estas gentes, al pasar a Argelia, se granjearían una merecida reputación de honestos, sobrios, expertos y laboriosos colonos.

Hacia 1840 el despegue industrial, localizado por el momento en contados puntos de la periferia del país, apenas dejaba sentir su benéfico influjo en el deprimido panorama provincial. Una agricultura arcaica no alcanzaba a soportar el peso de un territorio en franca expansión demográfica y con una industria apenas incipiente. El ferrocarril, las minas y el éxodo rural polarizado por Alcoy - único nucleo industrializado importante - y Alicante - su puerto era reputado un tanto hiperbólicamente por Madoz (28) como «el primero de España para la exportación al extranjero" - distaba de absorver la oferta de mano de obra. En consecuencia, no cabían otras salidas que el paro, es decir, la miseria, o la emigración a Argelia.

Tenemos datada emigración alicantina a la flamante colonia francesa desde sus comienzos mismos. Incluso en relación a localidades sin excesiva presión demográfica, como es el caso de Orihuela. Los emigrantes de esta localidad, de igual forma que los de todo el Bajo Segura y aún una parte de los murcianos, embarcaban en Torrevieja. Por cierto en condiciones francamente deficientes, a juzgar por lo sucedido en junio de 1843 a cierto emigrante oriolano, de profesión guitarrero, durante un viaje a Orán (29).

Desde la década de 1830 la emigración a Argelia sería el recurso obligado contra el paro y el hambre. La salida hacia la posesión francesa del

(27) Cfr ALTAMIRA Y CREVEA, p. 40.

(28) Diccionario geográfico-estadístico-histórico de España y sus posesiones de Ultramar. Madrid, 1849 , vol. I. p. 624.

(29) Vid. J.B. VILAR, Orihuela contemporánea... En prensa. Numerosas noticias sobre esta corriente migratoria en la documentación conservada en el AMO y en la prensa oriolana de la época. 
excedente laboral y la reinversión de ahorros en nuestra provincia, tendrá un doble efecto positivo. La promoción social en la ciudad de amplios sectores populares, y el creciente dominio en el ámbito rural de la pequeña y mediana propiedad.

Nada se da en Alicante que recuerde al levantamiento de Casabermeja y otras localidades malagueñas en 1840, a los motines de Sevilla, Utrera y Azahal de 1857, a las agitaciones campesinas de Málaga, Granada, Jerez, Sevilla y Córdoba en 1861 y años posteriores, o a la endémica inestabilidad de Andalucía en los años 80 y 90 . La conflictividad social - salvado el caso de Alcoy -, incluso en el Sexenio democrático estuvo aqui desprovisto de un maximalismo comparable al andaluz y el extremeño.

Bajo la Restauración, Alicante y su provincia conocen una expansión económica incuestionable, ante todo por la revalorización de sus caldos tras la ruina vinícola francesa. Las condiciones de vida de las clases trabajadoras tienden, empero, a evolucionar con signo negativo bajo los efectos de una presión demográfica sin precedentes. Argelia, Iberoamérica y Cataluña serán por largo tiempo las tres alternativas ofrecidas al jornalero en paro (30). Artola (31) estima que en el período 1858-70, de transición entre los ciclos migratorios africano y americano, la emigración capturaba la mitad del incremento vegetativo del país. El drenaje migracional se intensificaría en las décadas siguientes hasta revestir proporciones magnas en los años de 1890 y en los iniciales de la actual centuria.

\section{ESTIMACION CUANTITATIVA DEL MOVIMIENTO MIGRATORIO EN EL PERIODO 1882-1895}

Resulta difícil hacer una estimación cuantitativa de la emigración alicantina a Argelia en la fase precedente a 1882. Las estadísticas españolas sobre salidas y entradas de pasajeros por mar arrancan de ese año. Con anterioridad no existe otra información que la consular, por cierto bastante imprecisa. En cuanto a las estadísticas francesas, no recogen el origen por provincias de los emigrantes españoles.

El año 1885 fue el primero en que pudo lograrse un conocimiento bas-

(30) Vid. V. PALACIO ATARD, La España del siglo XIX. Madrid. 1978, ps. 315, 605608; M. MARTINEZ CUADRADO, La burguesía conservadora (1874-1931). Madrid, 1973. p. 82; J.A. LACOMBA, Estructura demográfica y dinámica social en la España del siglo $X I X$, en «Historia social de España. Siglo XIX». Madrid, 1972, p. 49; M. TUÑON DE LARA, La España del siglo XIX. Barcelona. 1973, p. 259 ss.

(31) La burgesia revolucionaria (1808-1869). Madrid, 1963, p. 66. 
tante completo del volumen de la emigración alicantina a Argelia: 4.460 individuos en un total nacional de 15.532. Un año más tarde salen de Alicante y demás puertos de la provincia con destino a la colonia francesa 8.852 emigrantes para un conjunto de 22.752. Alicante continúa ocupando un destacado segundo lugar en cuanto a emigración al Africa francesa, con tendencia a aproximarse a Almería, primera provincia de emigración a Argelia.

EMIGRANTES SALIDOS PARA ARGELIA (1885-1886)

Provincias de

última vecindad

Albacete

Alicante

Almería

Baleares

Barcelona

Castellón

Granada

Madrid

Málaga

Murcia

Valencia

Otras provincias

\begin{tabular}{|c|c|}
\hline \multicolumn{2}{|c|}{ Años } \\
\hline 1885 & 1886 \\
\hline 24 & 84 \\
\hline 4.460 & 8.852 \\
\hline 7.635 & 8.886 \\
\hline 584 & 713 \\
\hline 38 & 71 \\
\hline 66 & 130 \\
\hline 165 & 205 \\
\hline 41 & 72 \\
\hline 192 & 223 \\
\hline 1.425 & 1.937 \\
\hline 727 & 1.310 \\
\hline 175 & 269 \\
\hline & \\
\hline
\end{tabular}

Período

de

1885-1886

108

13.312

16.521

1.297

109

196

370

113

415

3.362

2.037

444

Totales

$\overline{15.532}$

22.752

38.284

Fuente: VILAR, Emigración española a Argelia, p. 107

Exceptuadas Madrid y Albacete, representadas con débilés contingentes migratorios, nos hallamos ante el compacto bloque de provincias españolas ribereñas del Mediterráneo, sin otras ausencias que las de Gerona, Tarragona y Cádiz, situadas en los flancos y bastante alejadas de Argelia. La cuantía de cada grupo migratorio se halla en relación directa a la proximidad de la provincia respectiva al territorio norteafricano. Mas de las tres cuartas partes de los emigrantes procedían, naturalmente, de Almería, Alicante y Murcia. Las siguen de lejos las provincias de Valencia y Baleares. A considerable distancia, Málaga, Granada, Castellón, Madrid, Barcelona y Albacete.

No resulta posible conocer con precisión los puntos de retorno. La 


\section{MOVIMIENTO DE PASAJEROS ENTRE ESPAÑA Y ARGELIA (1884-1914)}

MILES

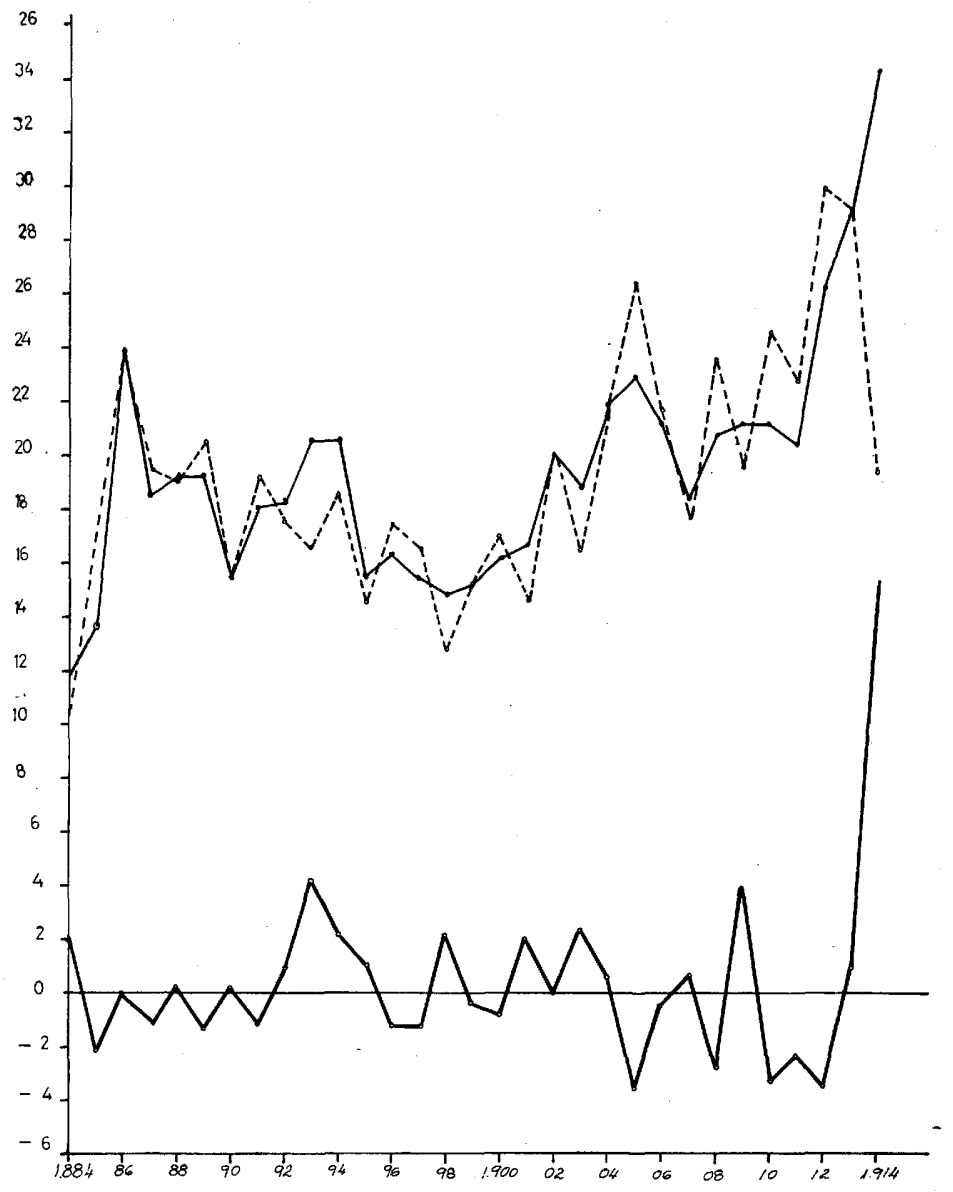

- ENTRADA

SALIDA 
provincia de destino no consta en las estadísticas correspondientes. Las cifras generales de entrada y salida por mar tampoco sirven a nuestro propósito. Incluyen a individuos de provincias interiores, pero sin especificar su origen. De otro lado, los emigrantes no entran ni salen necesariamente por su provincia de vecindad.

Según fuente oficial (32), «un tercio aproximadamente de los alicantinos comunican con la Argelia por los puertos de la provincia de Valencia; una cuarta parte de los domiciliados en ésta y algunos murcianos lo verifican por Alicante; los almerienses sólo, emigran casi todos y regresan por el puerto de su capital, salvo una pequeña parte que lo hacen por Cartagena».

Los datos referidos a Almería son, en consecuencia, los más fiables. El contingente alicantino que se servía de puertos valencianos en sus desplazamientos, parece equilibrarse con aquellos otros que, procedentes de ciertas comarcas interiores del sur de la provincia de Valencia, hallaban salida más cómoda por puertos alicantinos. Pero sobre todo numerosos murcianos preferían por razones de proximidad geográfica los embarcaderos alicantinos de Torrevieja y Guardamar al puerto de Cartagena.

Los indicios disponibles nos llevan a la conclusión de que en el quinquenio 1882-1886 el movimiento emigratorio con Argelia se halla próximo al equilibrio, con ligeros saldos favorables para la emigración de Alicante y Murcia. Solamente en el caso de Almería el número de salidas superó con amplio margen al de entradas.

La emigración a Iberoamérica y territorios españoles de Ultramar - Cuba principalmente - terminó relegando la corriente argelina a un plano secundario. Todavía en el bienio 1884-1885 las provincias conectadas a la colonia francesa ocupan lugares destacados en el cuadro migratorio del país. En 1884 Alicante, Almería y Murcia, con sus 4.140, 2.946 y 2.009 emigrantes, son la segunda, cuarta y sexta en cuanto al número de salidas, intercalándose con Pontevedra, La Coruña y Canarias.

Muy por detrás aparecen las demás provincias relacionadas con la posesión gala. Pero todas, en mayor o menor medida, tienden a desviar su centro de atracción hacia América. Un año después Almería figurará al frente de las provincias de emigración con 7.635 unidades (33). Supera en cifras absolutas a Pontevedra, La Coruña, Asturias y Canarias, de

(32) Estadística de la Emigración e Inmigración de España. Años 1882-1890. DEIGE. Madrid. 1891, p. 46.

(33) Vid. tabla 1 supra. 


\section{EMIGRACION ALICANTINA A ARGELIA (1885-1895)}

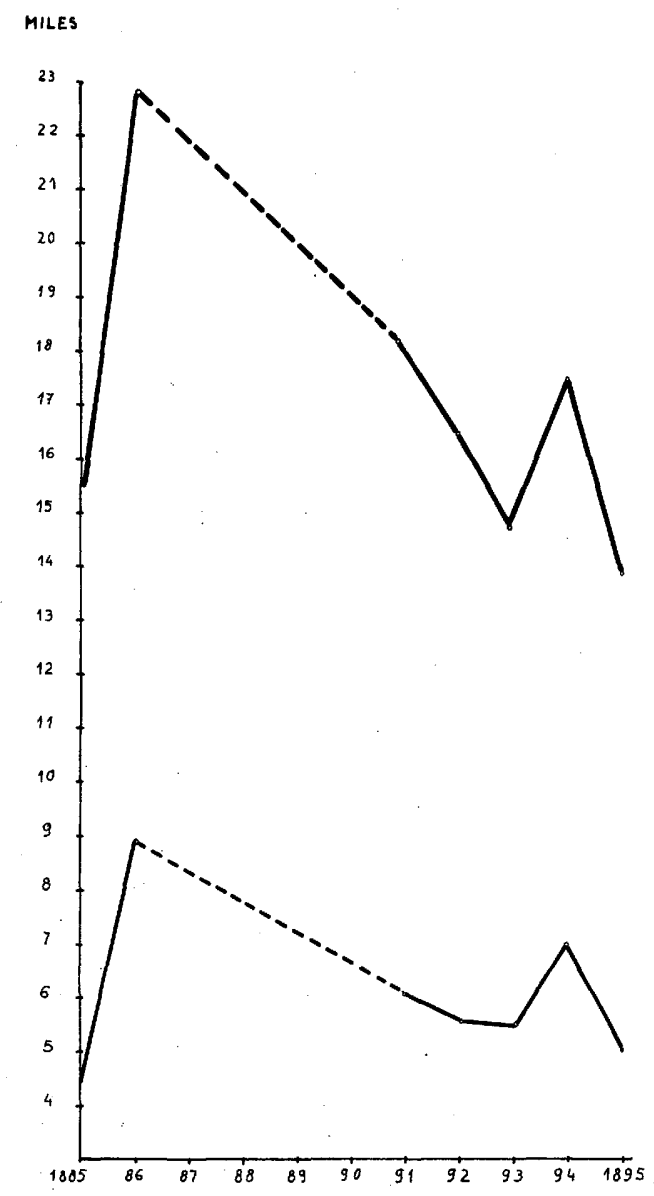

— Total contingente emigratorio de España

- Contingente emigratorio alicantino 
migración netamente transoceánica y monopolizadoras habituales de los primeros puestos en el cuadro de la emigración exterior española. Alicante con sus 4.460 salidas computadas se aseguraba, a su vez, un destacado lugar. Este sería todavía más relevante en 1886, en que el saldo migratorio alicantino se situa en función de Argelia prácticamente a igual nivel que el almeriense.

Veamos seguidamente las cifras correspondientes al lustro 18911895.

\section{CONTINGENTE POR PROVINCIAS DE LA EMIGRACION ESPAÑOLA A ARGELIA (1891-1895)}

\begin{tabular}{lrrrrrr}
$\begin{array}{l}\text { Provincias de } \\
\text { última vecindad }\end{array}$ & 1891 & 1892 & 1893 & 1894 & 1895 & 1895 \\
& & & & & & \\
Albacete & 91 & 109 & 169 & 244 & 122 & 735 \\
Alicante & 6.046 & 5.607 & 5.511 & 6.986 & 5.009 & 29.159 \\
Almería & 8.313 & 7.797 & 5.804 & 6.249 & 5.718 & 33.881 \\
Baleares & 346 & 276 & 396 & 470 & 546 & 2.034 \\
Barcelona & 25 & 32 & 51 & 40 & 23 & 171 \\
Castellón & 52 & 47 & 27 & 51 & 33 & 210 \\
Granada & 847 & 419 & 488 & 477 & 595 & 2.926 \\
Madrid & 59 & 70 & 37 & 33 & 15 & 214 \\
Málaga & 184 & 132 & 108 & 121 & 98 & 643 \\
Murcia & 1.382 & 1.203 & 1.496 & 1.829 & 1.179 & 7.080 \\
Valencia & 586 & 468 & 454 & 697 & 310 & 2.515 \\
Otras provincias & 160 & 310 & 175 & 186 & 153 & 984 \\
\multicolumn{1}{c}{ Totales } & 18.091 & 16.470 & 14.716 & 17.474 & 13.801 & 80.552
\end{tabular}

Fuente: VILAR, Emigración española a Argelia, p. 109

Almería continua siendo la provincia de máxima emigración a Argelia en el expresado lustro. Arroja un saldo de 33.881 salidas. Le sigue de cerca Alicante con 29.159. Murcia queda en tercer lugar con 7.080. Seguidamente figuran Granada, Valencia, Baleares, Albacete y Málaga con cifras fluctuantes entre 2.926 y 643 unidades.

Es de notar un descenso en los totales, comparados con los del periodo precedente. Salvo Granada y Albacete, provincias de débil emigración al norte de Africa, las demás experimentan una reducción apreciable en cifras absolutas, afectadas sin duda por el signo de los nuevos tiempos: la emigración a Ultramar y Cataluña. 
Los contingentes migratorios son aportados por las masas proletarias, o proletarizadas en fecha más o menos reciente, en momentos en que la sociedad española se ha polarizado en dos sectores antagónicos. Para J.M. Jover (34) ese hecho es consecuencia inevitable, aunque tardía respecto al resto de Europa, de la evolución económica hacia un capitalismo más avanzado, y de la difusión por la Península ibérica de las doctrinas ácratas y socialistas.

\section{COMARCAS DE EMIGRACION, RUTAS Y TRAFICOS. MOVIMIENTO CLANDESTINO DE PASAJEROS Y MERCANCIAS.}

La emigración alicantina procede ante todo de las pequeñas localidades litorales de la provincia, en continua comunicación mercantil con Argelia. Así Altea, Denia, Jávea, Calpe, Benidorm, Campello, Santapola, Torrevieja, Guardamar... etc.

Frágiles barquitos atestados de emigrantes en cuantos requicios dejaban expedidos una abundante carga, arribaban ininterrumpidamente al litoral argelino. La llegada de barcas con poco más de 25 toneladas transportando, aparte el cargamento habitual, otro adicional de entre 100 y 200 personas con sus equipajes y enseres, se halla a la orden del día. Vemos, verbigracia, presentarse en Argel en 1862, procedente de Jávea, un buque de 35 toneladas llevando a bordo 151 pasajeros con todo cuanto poseían, aparte la carga y siete tripulantes (35).

La afluencia a Argelia de embarcaciones, grandes y pequeñas, desde los puertos de la provincia de Alicante, llevando a bordo una turbamulta de braceros en busca de trabajo, con o sin documentación en regla, será la nota dominante en los primeros cuarenta años de la colonia. Hacia 1845 la emigración revestía dimensiones tales, que el cónsul general de España en Argel se sintió en la obligación de poner sobreaviso al gobierno de Madrid. En un despacho (36) dirigido a Martínez de la Rosa, ministro de Estado, atraerá su atención sobre la «emigración» espantosa de españoles que se verifica en este país, ya sea de la isla de Menorca, que según me aseguran va quedando desierta, ya de la costa del continente, particularmente de la parte de Alicante, que según la marcha que lleva, no tardará en quedarse también como la isla de Menorca».

No se presentaba barco de España que no fuese saturado de emigrantes. Las condiciones de la travesía eran dignas del peor tráfico negrero.

(34) Conciencia burguesa y conciencia obrera en la España contemporánea. Madrid. 1952, ps. 41-42.

(35) AMAE, Correspondencia (Argel). leg. 1819.

(36) Ibidem, Política, leg. 2.311 
Barcas de pesca y diminutos laudes y faluchos de no más de veinte toneladas admitían hasta doscientos o más pasajeros, «apiñados sobre la cubierta como una manada de carneros, con grave exposición de sus vidas, pues la mayor parte de estos buques llegan sobrecargados de frutas") (37).

Por fortuna el trayecto era breve, aunque no tanto como para quedar a cubierto de los frecuentes siniestros registrados en las movidas aguas de Argel, acompañados de largas listas de muertos y desaparecidos. Los informes evacuados en esta época por el vicecónsul en Orán no resultan más alentadores.

Orán y su región absorbía buena parte de la inmigración peninsular, en tanto el Argerois y en menor medida el Constantinois - transpaís de Argel y Bona respectivamente - polarizaban la emigración balear. Pero el alicantino se encuentra en todas partes. Dominaba de forma incontrastable el panorama de la inmigración española en la Oranie, no obstante el tardio aunque breve protagonismo almeriense. Su presencia se dejaba sentir en todo el país desde Arzew, en la frontera marroquí, a Bona, en la raya con Túnez. Desde los puertos litorales a las altas mesetas de Saida y Tiaret, y a las planicies subdesérticas más meridionales.

El tráfico de pasajeros resultaba inseparable del de mercancías. En una interesante memoria consular fechada en 1862, referida al movimiento comercial del año precedente entre España y Argelia, se situa este tráfico, en cuanto a volumen, en segundo lugar en el conjunto del comercio exterior argelino, inmediatamente a continuación del sostenido por la metrópoli con su colonia. Era realizado por embarcaciones españolas, en general de escaso calado, e introducía en Argelia ante todo vino alicantino, seguido de frutas frescas, manufacturas de espartería y legumbres secas como partidas más destacadas. El azafrán meseteño era objeto de intenso tráfico clandestino. Las importaciones españolas, de inferior cuantía, consistían en tabaco, cereales, cueros y ganado vivo principalmente (38). En líneas generales el comercio hispano-argelino presentaba iguales características que veinte años antes al iniciarse la colonización (39).

(37) Ibidem.

(38) J.B. VILAR, Transformations agraries algériennes au milieu du XIXe siécle et crise economique de 1861, selon un memoire du consulat d'Espagne a Alger. Revue d'Histoire Maghrebine, 19-20 (Tunis, 1980), ps 185-197.

(39) VILAR, Le commerce espagnol avec l'Algerie au debut de la periode coloniale. Revue d'Histoire Maghrebine, 12 (1978), ps. 286-297. (Reproducido con incorporación de apéndices originales en el "Bulletin de la Societé de Geographie er Archeologie d'Oran», au 1977-1978, ps. 124-145); VILAR, Alicante en el tráfico español con Argelia (1870-1833). Revista del Instituto de Estudios Alicantinos. 22 (1978), ps. 75-90. 
«El vino - apunta nuestro informante $(40)$ - procede en su mayor parte de los puertos de Alicante y Santa Pola. Se cosecha en Elche, Monóvar y Novelda. Su gusto abocado lo descalifica como vino ordinario de comida. Hoy tiene aceptación este caldo en el mercado por la carestía y encarecimiento del de Francia, pero si los cosecheros aspiran a la preferencia tan apetecida en el tráfico, deben evitar su práctica de cosechar las uvas demasiado maduras, procurando impedir que luego se soben. También deberían clasificarlo por los medios fáciles y sencillos adoptados hoy por la industria. De este modo sería el vino seco, sin ser áspero, y alcanzaría la estimación que merece la bondad de sus condiciones». El incremento de la demanda solía conllevar no pocos abusos, en particular la adulteración de caldos en los puntos de origen o destino, hecho al que, según parece (41), no eran ajenos especuladores franceses.

Durante los años sesenta subsisten los caracteres del tráfico apuntado. Transporte de personas y mercancías en pequeñas embarcaciones y comercio deficitario para Argelia, no obstante la potenciación de nuevas exportaciones argelinas, como algodón, esparto, coral y carbón vegetal (42).

En cuanto se refiere a la provincia alicantina, se detecta la captura de una parte considerable del tráfico por Alicante, puerto conceptuado como de primera clase y habilitado por toda suerte de operaciones de importación y exportación. Tales operaciones, con algunas restricciones, podían ser practicadas por los puertos de segunda, entre los cuales no figuraba ninguno alicantino. Por el contrario, Denia estaba conceptuada como puerto de tercera, autorizado a practicar un comercio exterior restringido. Eran de cuarta los de Altea, Jávea, Santapola, Torrevieja y Villajoyosa, a los que se les permitía únicamente el cabotaje y la exportación de vinos en pipas devueltas vacías (43). Excluidos prácticamente del tráfico legal de Argelia, los pequeños puertos alicantinos realizarían otro clandestino no menos activo y desde luego más lucrativo.

El contrabando nunca pudo ser erradicado, favorecido por toda suerte de circunstancias propicias y de complicidades. En el comercio de

(40) VILAR, Transformations agraires... p.194.

(41) Vid. Apéndice IV.

(42) M. MALO DE MOLINA, Viaje a la Argelia. Descripción geográfica y estadistica del Africa francesa. Valencia, 1852, p. 43. Una excelente visión de conjunto de estos intercambios en el contexto general de la posesión francesa la encontramos en T.LAUJOULET, Le commerce en Algérie. Essai sur le peuplement utile de l'Afrique française. Paris 1860 [280 ps].

(43) M. CARRERAS Y GONZALEZ. Curso de Geografía y estadistica industrial y comercial. Madrid. 1866, ps. 134-138. 
Alicante con Argelia no siempre resulta fácil separar el tráfico legal del clandestino. Los pequeños faluchos alicantinos, los transportes de emigrantes, los pesqueros de la Marina, Santapola y Torrevieja, olvidaban con frecuencia registrar su carga de retorno, sobre todo si lo hacian desde Mazalquivir, puerto franco dotado de depósitos de mercancías gibraltareñas. Naturalmente no faltaba el patrón con dedicación específica al contrabando, que en su velero o en su vaporcillo hacía la alijada en sendas noches consecutivas.

El tabaco, argelino o no, merecía atención preferente del contrabandista por su elevada cotización, escaso volumen, peso liviano y sobre todo por su fácil colocación en la Península. Las manufacturas británicas y francesas ocupaban también un lugar destacado en este tráfico ilícito. Por último, los cereales y el algodón. «Bien puede decirse - hubo de convenir en agosto de 1864 el consul español en Argel en uno de sus despachos a Madrid (44) - que es casi seguro que todos los buques españoles que hacen la navegación entre la colonia y los diferentes puntos de la Península, mas o menos se dedican a toda clase de contrabando"».

Tráfico por cierto estrechamente conectado a otro asi mismo ilícito, el de personas. La práctica de la falsificación de cédulas de identidad y pasaportes (45) alternaba con la introducción en Argelia, por desaprensivos patrones, de emigrantes enteramente indocumentados (46), llamados luego a ser objeto de inicua explotación.

En los duros años de 1860 y 1870 la Península vomitó sobre las playas argelinas una turbamulta afanosa de abrirse camino. Una buena mitad procedia de la provincia de Alicante, superpoblada como siempre, y sobre la que se dejaba sentir con mayor rigor los efectos de la adversa coyuntura económica. Esta es la causa principal apuntada por el cónsul español en Orán para la potente emigración alicantina, aunque no la única. La proximidad entre ambas costas, el bajo costo del viaje y las facilidades encontradas por el emigrante para abandonar el país, justifica a su vez las proporciones desorbitadas alcanzadas por esa emigración. "Hoy día - subraya el funcionario hacia 1868 (47) - consta a este consulado que en las provincias de Alicante, Murcia y Almería, y particularmente en la primera, no se atiende con aquel celo e interés que merece esta cuestión; pues sólo con apuntar que durante el año finalizado

(44) AMAE, Correspondencia (Argel), leg. 1818. Vid. también VILAR. La conyuntura argelina de 1866 a través de un informe confidencial español. Cuadernos de Historia Moderna y Contemporánea, 1 (Murcia. 1982). En prensa.

(45) Apéndice II.

(46) Ibidem VIII.

(47) AMAE, Correspondencia (Orán), leg. 1997 
se han dado para esta 473 pasaportes originales para pobres de solemnidad... se hará cargo V.E. de mis asertos. Esta facilidad de pasaportes gratuitos atrae, además del primer mal que es la despoblación, el de acarrear a tantos desgraciados una vez llegados a esta, diversas incomodidades propias de su precaria y falsa situación, teniendo entonces que recurrir al consulado de S.M. solicitando los auxilios convenientes para su regreso a España, de lo cual resulta un doble gravamen para la nación». Hasta 1882 no se inició un esfuerzo serio y continuado de reglamentación de esa emigración (48), justamente en el momento en que Argelia comenzaba a ser preferida ante Iberoamérica en el panorama de los movimientos migratorios exteriores españoles.

\section{5. - EL ÓRANESADO, REGION DE INMIGRACION}

Si la emigración balear - en menor medida la valenciana y una parte de la alicantina-, según ha sido apuntado, se centró en los departamentos de Argel y Constantina, es decir en la Argelia centro-oriental, la suresteña por consideraciones ante todo de proximidad geográfica, incidirá de lleno sobre el departamento mas occidental, la Oranie u Oranesado.

Durante el segundo tercio del XIX predomina el elemento alicantino y murciano, conectado de antiguo a Orán a través de Alicante y Cartagena. Sólo después de 1850 se detecta una creciente afluencia de almerienses, coincidiendo con la decadencia de las minas de Almagrera. Pero hasta los años de 1880 el dominio de Almería en el panorama migratorio hispano-argelino no será incuestionable en cuanto a cifras absolutas, y aún entonces por breve tiempo. El inmigrante alicantino fue casi siempre sostén y columna de la colonización.

Emile Violard (49) ha dedicado a esa inmigración en el Oranesado páginas tan reales como sugestivas. "Acompañados de sus mujeres y una bulliciosa prole - escribe-, llevaban consigo por todo equipaje un colchón, una sartén, un zapapico y algunas mantas. Tan pronto como se reponían de las fatigas del viaje, después de algunos días de campamento en los muelles de Orán, los españoles se marchaban a la aventura en rebaños resignados; las jóvenes, los pequeñuelos al brazo, en tanto las viejas, las abuelas, cuidaban de aquellos que esperaban la «edad de

(48) J.B. VILAR, Quelques consecuences en Espagne du soulevement algérien de 1881 (dans les courants migratories hispano-algériens et dans les relations hispano-françaises. Melanges de la Casa de Velazquez (Paris-Madrid). 1982. En prensa.

(49) Les villages algériennes. Alger. 1925-1926. vol. I. ps.60-61. 
razón» y que podían caminar cogidos de sus faldas (...). Se iban así curtidos y destrozados; abrumados bajo el fardo de la miseria, hacia lo desconocido, en busca del pedazo de pan que esperaban encontrar en el interior del país (...). El dinero que recibian en remuneración de trabajos, los beneficios que obtenían en la producción de carbón, la cria de cerdos, los trabajos en las huertas, en la venta de sus productos y el contrabando, porque en estos tiempos bajo la capa de todo buen español latía un corazón ardiente de audaz contrabandista, les permitía reunir un pequeño peculio y podían entonces extender su comercio, adquirir propiedades y llamar del pueblo natal a sus parientes y amigos».

He ahí los orígenes de la colonización europea en la Oranie. Los jornaleros miserables de la España mediterránea se desparramarán por todo el territorio roturando baldíos, abriendo caminos, desecando marismas y pantanos, descuajando matorrales, introduciendo nuevos cultivos, tendiendo las primeras vías férreas y empleándose en los duros trabajos inseparables a la puesta en marcha de toda colonización. En algunos pueblos la totalidad de sus moradores eran españoles, sin otra excepción que los funcionarios locales, dándose el caso insólitos de que la municipalidad tuviese que echar mano de intérpretes para hacerse entender del vecindario (50).

Los inmigrantes se anticipaban incluso a los propios soldados franceses al penetrar, no sin riesgo de sus vidas, en territorios todavía insumisos. Son de destacar las actividades de los carreteros alicantinos en sus arriesgados viajes para aprovisionar aldeas, cortijadas y acuartelamientos, que "sin escolta, sin caminos ni puentes, a través de malezas, barrancos y montañas, supieron cumplir con su cometido con notoria eficacia»... (51). La labor de estos carreteros resultaba tan fundamental para la supervivencia de la naciente Argelia francesa como la desplegada con sus frágiles barquichuelos por patrones de Baleares, Alicante y Valencia en el cabotaje de la colonia.

El español - alicantino, murciano o almeriense - aparece por doquier. «Mientras los metropolitanos llamados por la Administración - refiere un experto (52) - se aclimataron difícilmente en un suelo muy distinto al suyo, la colonización ulibre», compuesta por emigrantes de diferentes países, de regiones mediterráneas, se desenvuelve con facilidad. No existe para ella - añade - el socorro de la Administración, ni se

(50) VILAR, Emigración española a Argelia...,p. 131.

(51) VILAR, Los españoles en la Argelia francesa... Op. cit.

(52) A.L. FERNANDEZ FLORES, Argelia y los españoles. BDGE. I. núms 2-3. (1929-1930), p. 626. 
les construye casas, ni se les prepara el suelo, y son los que la componen los primeros que abren el camino a los nuevos colonos, estableciéndose en los alrededores, ofreciendo su cuerpo como blanco al enemigo. Estos hombres, que quizá no fuesen lo mas destacable dentro de una sociedad constituida, son aquí el gran elemento para la colonización, y logran con su propio esfuerzo el éxito que se niega muchas veces a la colonización organizada».

Singularmente en la Argelia occidental su papel resultó fundamental. "Venían los españoles - apunta cierto cronista francés de una localidad aranesa (53) - sin aprehensión, sin perjuicios. No hay que lamentarlo, pues estos obreros tenaces, duros en el trabajo y sobrios, que nos enviaron las provincias de Valencia, Alicante y Almería, contribuyeron esencialmente a la prosperidad agrícola de la región.»

Los efectivos alicantinos en la colonia se multiplicarán de tal forma en los años sesenta que, a juzgar por informes consulares (54), los individuos oriundos de la provincia de Alicante figuran muy por delante en cuanto a efectivos respecto a los restantes grupos componentes de la nutrida colectividad española. Se componia ésta en su mayoría de jornaleros, arrendatarios, modestos propietarios agrícolas, tenderos y artesanos. "A excepción de D. Salvador Coll, que en las inmediaciones de Bona posee 10.000 hectáreas de tierras - informa el consul en Argel en febrero de 1860 (55) - , no hay en Argelia ningún español notable por su riqueza y posición. Aún en esta capital, salvo tres o cuatro comerciantes, todos son tenderos, jornaleros o pescadores. En la provincia, bastantes poseen pequeñas concesiones y se dedican a la agrícultura».

En Orán y su distrito, a su vez, eran por entonces 30.000 . Una cuarta parte labradores y comerciantes; otra cuarta parte artesanos y obreros, y el resto, jornaleros rurales uexpuestos a todos los azares de la suerte y a los peligros de la miseria» (56). Se ocupaban en las faenas agrícolas, en la recolección de esparto, en trabajos de desmonte o en el tendido del ferrocarril Argel-Orán.

Dentro de la temporalidad inicial de la emigración alicantina a Argelia, el tipo golondrina fue el mas frecuente. El bracero, realizadas las sementeras de otoño, marchaba al vecino país africano para zafarse a los efectos del paro. El regreso tenía lugar en junio, coincidiendo con el comien-

(53) L. ADOUE, La ville de Sidi-bel-Abbés. Historie. Legénde. Anecdotes. Sidi-belAbbés. 1927, p. 53

(54) AHN, Estado, legs. 6154, 8357; AMAE, Correspondencia (Orán), legs. 1997-1999

(55) Apéndice VI.

(56) AMAE, Correspondencia (Orán), leg. 1997. 
zo de la siega en la Península. En años de sequías, plagas e inundaciones, la paralización de los trabajos imprimía al exódo proporciones desmesuradas.

La proximidad de Argelia, su similitud en clima y paisaje a la provincia de Alicante, la rapidez y bajo costo del viaje, la facilidad del retorno, la certeza de encontrarse entre compatriotas y amigos, la seguridad de hallar ocupación, y el recuerdo de provechosas experiencias precedentes, representaban incentivos irresistibles para el atribulado jornalero. En un par de meses los temporeros hacian un ahorro entre 100 y 300 francos, suma que, convertida en pesetas, se incrementaba en un $30 \mathrm{y}$ un 50 por ciento. Aproximadamente la mitad de su salario anual en la Península, deducidos los meses de paro estacional.

No todos regresaban. Concluidas las faenas para las que fueron contratados, permanecían en el país quienes lograban asegurarse una continuidad laboral. Llamaban entonces a sus familias y la emigración golondrina se hacía temporal, paso previo para su conversión en definitiva. Es asi como una población flotante sedimentó otra estable, arraigada en el territorio, de forma que la colectividad española terminó siendo la extranjera más numerosa, hasta superar a la metropolitana en la Oranie, región predominantemente hispánica.

Desde 1870 , coincidiendo con una gran afluencia de jornaleros peninsulares, los progresos de la colonización correrán parejos con la expansión del atochal, una de las principales fuentes de riqueza en el tercio final del siglo. Las empresas explotadoras facilitaban a los operarios el pasaje de ida, cuyo importe era deducido de los primeros jornales. El trabajo se hacía a destajo, pagándose entre 2,25 y 3 francos por cien kilogramos de esparto verde puesto en la báscula (57). La lejanía de los atochales a los nucleos de la población obligaba al recolector a hacer sus compras en las cantinas de las compañías. habiendo de satisfacer por lo general precios abusivos a juzgar por las reiteradas denuncias formuladas por los cónsules (58). De otro lado, los anticipos pecuniarios y la recogida de cédulas personales en el momento de la incorporación al trabajo dejaba al jornalero a merced del patrón.

Esta inmigración de última hora era, empero, fundamentalmente almeriense y murciana. Un ejemplo nos ilustrará. De los 6.343 temporeros españoles desembarcados en Orán en agosto y septiembre de 1879 sólo 1.533 prodecían de Alicante.

(57) VILAR, Emigración española a Argelia..., p. 256.

(58) AMAE, Correspondencia (Orán), leg. 2.000. 
Puerto de

Número de

procedencia

inmigrantes

Almería

Cartagena

Alicante

Total

Fuente: AMAE, Correspondencia (Orán), leg. 1998

Las cifras se refieren a quienes adquirieron pasaje en vapores entre la capital de la Oranie y esos tres puertos suresteños. No se incluye, en consecuencia, a quienes se sirvieron de otros medios de transporte - veleros, barcos de pesca... etc. - a los que llegaron procedentes de los demás puertos españoles y a aquellos que desembarcaron en alguna de las restantes localidades litorales argelinas.

Después de 1881, olvidados rápidamente los sucesos de Saida - muerte de un centenar largo de españoles sorprendidos por los cabileños cuando recolectaban esparto (59) - , una vez aplastada por los franceses la revuelta argelina, se reanuda la inmigración con tal empuje que fueron rebasadas las cotas precedentes. Este género de peligros, tan frecuentes en la fase anterior (60), remitirán una vez consolidada la situación francesa en Argelia.

El destino inicial del emigrante era el ámbito rural. Desde el puerto de Orán se les conducía de inmediato a las comarcas del interior. Sobre todo a las altiplanicies sur-oranesas, donde se les empleaba en los trabajos más duros. Por doquier les hallamos con sus familias amontonados en sórdidas chabolas de una sola habitación, los "gurbis», cuyo mobiliario y menaje no difiere gran cosa del usual en las viviendas musulmanas más modestas. El mueble principal es la gran cama situada en la mitad del cuarto, donde el jefe de familia descansa y procrea. En torno a ella la

(59) Vid. pormenores en VILAR, Quelques consequences en Espagne du soulevement algérien de $1881 . .$. Op. cit.

(60) Vid, por ejemplo, el caso de cierto número oriundo de Elche capturado con otros dos compañeros cuando trabajaba en las proximidades de la rạya de Túnez - Apéndice $\mathrm{VI}$ - . El director de la mina hubo de satisfacer 2.400 francos en concepto de rescate. Vid. AMAE, Correspondencia (Argel), leg. 1819. 
numerosa prole, los viejos y parientes, duermen en el suelo. Estos sarmentosos inmigrantes serán nervio y alma de la colonización.

Después de vivir en condiciones infrahumanas durante unos años y habiendo ahorrado hasta el último franco, comprarán tierras o abrieran un pequeño negocio en las ciudades. En Orán y Sidi - bel- Abbés preferentemente.

Su presencia se deja sentir por todas partes. «Es así - refiere el representante diplomático en Orán a finales de siglo (61) - que en esta población hay calles y hasta barrios completamente españoles. Del interior y de las costas de este departamento no diré más sino que el viajero atraviesa aldeas y pueblos enteros donde no se oye hablar más que nuestro idioma».

Rená Huertas (62), alto funcionario argelino de origen español, nos ha transmitido preciosas noticias sobre la vida de los alicantinos, y de los españoles en general, en el Oranesado finisecular. Un compatriota suyo, refiriendose a la capital departamental, dirá que Orán no era indígena, pero tampoco francesa. "Por todas partes - dice (63)-se ven hombres en mangas de camisa, con alpargatas de esparto, polainas desabrochadas, faja negra a la cintura y una manta de color oscuro. Son españoles. Dueños de Orán en dos ocasiones, parece que lo son todavia».

Instalados en el país, frecuentaban la compañía de sus connacionales, matenian relaciones por lo general cordiales con musulmanes (64) y judíos (65), a quienes trataban con aires de cierta superioridad, y motejarán al francés de "sopero» y "gabacho», pero a su vez serán vistos por el colono oriundo de la metrópoli como miserables y soberbios intrusos, a quienes era preciso tolerar por resultar imprescindibles. "¿Qué vienen a hacer en nuestras posesiones, dicen amargamente nuestros colonos - refiere el doctor Bernard (66) - , esos Pepes turbulentos y batalladores, cuyas serenatas nos rompen la cabeza, que atropellan a nuestros

(61) AMAE, Correspondencia (Orán), leg, 1997.

(62) AO, R. HUERTAS Les populations espagnoles et d'origine espagnole en Oranie. Orán. 1951. fols. 32-38.

(63) Dr. BERNARD, La Argelia. Madrid. 1891, ps. 229-230.

(64) VILAR, Sociedad española en la Argelia otomana (1791-1814). Almenara, 9 (Madrid, 1976), ps. 63-72; VILAR, Emigración española a Argelia... ps. 390-393.

(65) VILLAR, Los judios de Argel, Orán y Gibraltar, intermediarios del tráfico hispanoargelino entre 1791-1830: asunto Bacri. Miscelánea de Estudios Arabes y Hebráicos, 24, fasc. 2 (Granada, 1975), ps. 67-73; VILAR, Notas sobre relaciones hispano judias en Orán en e/ siglo XIX. Revista del Instituto de Estudios Alicantinos, 16 (1976), ps. 63-70; VILAR, Emigración española a Argelia... ps, 393-400.

(66) La Argelia..., p. 230. 
agentes y que no han perdido la costumbre de desesperar a los alcaldes?. Y si no hicieran mas que tocar la guitarra! Pero manejan con gusto la faca, ese pequeño cuchillo con el que se saben teñir de rojo las camisas blancas ; Que vayan a colonizar sus Carolinas!».

Conservaban ciudadosamente costumbres y folklore. Sus platos preferidos eran el potaje, la paella y el gazpacho. Se mostraban corteses y hospitalarios con los extraños y muy comunicativos entre iguales. Miraban las apariencias y gustaban de quedar bien. No dudaban hacer un dispendio para mantener la reputación. Eran orgullosos y, llegado el caso, puntillosos, vengativos y brutales.

Entrado el siglo XX florece la civilización española en la Oranie por obra y gracia de los alicantinos. Orán y otras localidades importantes de la región cuentan con un teatro español, una prensa en castellano $-y$ en ocasiones incluso en valenciano-, asociaciones filantrópicas y culturales primitivamente españolas, y hasta fallas y plaza de toros (67). Las comunicaciones e intercambios de todo orden entre Orán y Alicante eran asiduos, e irrecusable la influencia alicantina sobre los géneros de vida de la región (68).

"Se les ve circular como por su casa - apunta cierto observador francés (69) - gravemente, con zaragüelles blancos, polainas de lana y la manta valenciana en banderola». Que duda cabe de que los alicantinos fueron las hormigas y abejas de la gran colmena oranesa, y elemento decisivo en la plasmación de un nuevo pueblo, el pueblo europeo de Argelia.

\section{CONCLUSIONES}

Las migraciones ochocentistas de alicantinos a Argelia son parte importante de las españolas dirigidas al norte de Africa en el XIX. Se inician hacia 1830, anticipándose en treinta o cuarenta años a las dirigidas a la América continental. Cuantitativamente superaron al éxodo de las restantes provincias con igual destino, exceptuando el caso almeriense durante un breve intervalo finisecular. El ciclo migratorio alcanzó su techo en la decada de 1880 para declinar después por causas diversas, en particular la desviación migracional hacia Iberoamérica.

Emigración fundamentalmente golondrina, la hubo también temporal e incluso definitiva. Contribuyó destacadamente al poblamiento euro-

(67) Numerosas noticias en VILAR, Los españoles en la Argelia francesa, Op. cit.

(68) Ibidem.

(69) C. DESPREZ, Voyage a Orán. Argel, 1872, ps. 181. 
peo de Argelia y posibilitó la preponderancia del elemento hispánico en la Oranie.

Ese drenaje de población contribuyó sin duda al estancamiento demográfico y económico de las areas más deprimidas de la provincia de origen, efecto negativo contrarrestado en parte por otros positivos. En particular la disminución de los niveles de conflctividad social en relación con las provincias andaluzas por ser inferior la presión demográfica $-y$ el desempleo - y la transformación en alguna medida de la estructura de la propiedad como resultado de la reinversión de los ahorros del emigrante.

Por último, esta emigración laboral conllevó otra de delincuentes, presidiarios huidos y prófugos (70), aspecto poco conocido pero con negativa incidencia sobre las relaciones hispano-francesas y sobre la imagen de los españoles en la colonia. A su vez, se daría una cuantiosa emigración política (71), hasta el punto de que la totalidad de las oposiciones españolas ochocentistas desfilaron por Argelia.

\section{ABREVIATURAS UTILIZADAS}

ADA: Archivo de la Diputación Provincial de Alicante.

AHN: Archivo Histórico Nacional (Madrid).

AMAE: Archivo del Ministerio de Asuntos exteriores (Madrid).

AME: Archivo Municipal de Elche.

AMO: Archivo Municipal de Orihuela.

AO: Archives d'Outre - Mer (Aix - en - Provence).

BDGE: Boletín de la Dirección General de Emigración.

DGIGE: Dirección General del Instituto Geográfico y Estadistíco.

(70) Vid. Apéndices $\vee$ y X. Aproximación al tema en VILAR, Emigración española a Argelia..., ps. 301-312.

(71) Análisis pormenorizado de la misma en VILAR, Emigración española a Argelia ...., ps. 313-363. Datos adicionales en VILAR, Los españoles en la Argelia francesa... Op. cit. Vid. un caso concreto conectado a Alicante y su provincia en Apéndice IX. 


\section{APENDICE DOCUMENTAL}

1. Depresión, miseria y emigración en el agro alicantino de mediados del siglo XIX: según, un informe del capitán general de Valencia (enero, 1846) (1).

Excmo. Señor:

El capitán general de Valencia, en 23 del actual, me dice lo siguiente:

«Enterado por la Real orden que V.E. se sirvió comunicarme con fecha 6 de diciembre próximo pasado, de los deseos de S.M. respecto a que manifestase cuales pueden ser en mi concepto las causas que podrán influir en la emigración que se nota a las posesiones francesas en Africa desde las costas del continente en la parte de Alicante, tomé los conocimientos que creí oportunos para poder cumplimentar la expresada Real resolución, y de ellos me resulta:

Que prescindiendo de que tanto en la capital de aquelia provincia como en los pueblos de su huerta no se conoce otra industria mas que la agricultura y mercantil, ambas en estado muy mezquino. La agricultura es la principal ocupación de los habitantes del territorio, del que forman parte treinta y dos mil tahullas pertenecientes a la huerta de la ciudad, regadas con aguas que se reunen en el Real pantano de Tibi, parte de lluvias y parte de las fuentes que nacen en los términos de Ibi, Tibi y Castalla, caudal de continuo bastante escaso para su objeto y siempre precario, porque depender de la abundancia de lluvias en las estaciones oportunas o de la sequía que desgraciadamente se experimenta, resintiéndose de consiguiente los manantiales que vertían sus aguas en el pantano, en términos que los labradores de los pueblos de la huerta y caserios inmediatos de Muchamiel, San Juan, Benimagrell, Santa Faz, Villafranqueza y San Vicente se hallan arruinados a causa de la sequía continuada por tantos años que les ha privado de la cosecha con que contaban para el sustento propio y de sus familias, y cumplir además con sus obligaciones respectivas.

En el año próximo pasado ni aún les ha sido posible practicar la sementera por falta de aguas pluviales. En tan dura situación no es dudosa ni extraña la determinación que aquellos infelices habitantes han tomado en la triste alternativa de perecer de hambre con sus familias o de emigrar pasando a las vecinas costas de Africa, donde se les brinda (oportunidades) con pingües jornales y aún con tierras de cultivo en propiedad mediante un módico canon anual.

De semejante medida, adoptada por los labradores de la huerta de Alicante, si bien resulta la conservación de sus dias, aunque a fuerza de trabajo, también la falta de sus brazos causa la decadencia de la provincia, porque sobre quedar ésta bastante despoblada, podria sostenerse ésta y aquellos con sólo promover obras públicas de consideración e importancia donde, pudiendo emplearse los robustos brazos de los emigrados hasta ahora y de los que en adelante pudieran verificarlo a ejemplo de los primeros, encontrarian unos y otros los medios de subsistencia precisa, mientras la provincia se aprovecharia de sus trabajos en beneficio público y permanente.

Este es a mi parecer el medio a que pudiera apelarse en la ocasión presente para contener en algún tanto la emigración que se experimenta. Para cortarla de raíz y mejorar la suerte de la provincia de Alicante, fertilizando sus campos y haciendo ricos a sus labradores - si pudieran conseguir otros recursos que aseguren el cultivo de sus huertas como en otras ocasiones lo han solicitado - que se les cedan los aluviones que engrosan él rio Júcar, aprovechándolos en su beneficio sin detrimento y perjuicio de los habitantes de Valencia, que están en derecho y posesión de las aguas de dicho rio. Más sobre asunto tan interesante para ambas provincias limitrofes tiene ya extenso conocimiento el gobierno de

(1) AMAE, Política, leg, 2.311: Notificación de Narváez al Ministro de Estado, Madrid 31 enero 1846. 
S.M., sin que a mí me sea dado informar de parte de cual de las dos provincias está la justicia, según sus reclamaciones y oposición.

Lo que comunico a V.E. en cumplimiento de lo preceptuado en la citada Real resolución para que, sirviéndose elevarlo a conocimiento de S.M. si lo estima conveniente, pueda recaer la determinación que sea del Real agrado».

De Real órden lo digo a V.E. en contestación a su escrito de 4 de diciembre último sobre el mismo objeto. Dios... etc. Madrid 31 de enero de 1846. EL DUQUE DE VALENCIA.

Sr. Ministro de Estado. (2).

\section{Clandestina emigración desde Alicante a Orán (marzo-abril, 1851)}

\section{Generalizada falsificación de pasaportes (3)}

Excmo. Señor:

Muy Señor mio: Tan luego como vicecónsul de S.M. en Orán recibió la carta del perfecto de aquella provincia, de (la) que he tenido el honor de dirigir a V.E. una copia con $\mathrm{mi}$ despacho $n^{\circ} 46$ de fecha 3 de este mes relativa al gran número de españoles que desembarcan en la costa de aquel departamento con pasaportes que él llama falsificados, porque sobre pasaportes regulares dados por las autoridades se añaden, mediante una cierta suma, muchas personas calificándolas de tíos, hermanos, etc., ocasionando grandes dificultades a la administración por no poder conocer los nombres de los españoles que vienen con estos pasaportes, y a las medidas severas adoptadas por aquella autoridad para arrestar y poner a la disposición del procurador de la República a todo español portador o cómplice de pasaportes de esta clase, se dirigió por la primera ocasión de buque que se le presentó al señor gobernador civil de la provincia de Alicante, dándole comunicación de aquella determinación de la autoridad del departamento, para que procurase hacer vigilar los embarques de pasajeros que se verifican en aquella provincia, e impedir el que vengan a este país con pasaportes irregulares o falsificados en los términos que señala el prefecto.

El vicecónsul de S.M. me remite con su oficio $n^{\circ} 43$ y fecha de marzo pasado la contestación que le dirige el señor gobernador civil de Alicante, asegurándole que adoptará cuantas medidas juzgue necesarias para impedir que nuestros patrones conduzcan a las costas de la Argelia a españoles que se hallen en el caso señalado por el prefecto.

Todo lo que tengo el honor de poner en conocimiento de V.E. para los fines que convengan.

Dios... etc. Argel 4 de abril de 1851.

Excmo. Señor, b.l.m. a V.E. su más atento y seguro servidor, VICENTE DE ZUGASTI.

Excmo. Sr. Dn. Manuel Beltrán de Lis, primer Secretario de Estado y del Despacho. Madrid.

\section{Se estrecha la vigilancia en Alicante (4)}

Gobierno de la Provincia de Alicante.

Dirección de Gobierno.

He recibido la atenta comunicación de V.S. de 26 de febrero último, juntamente con la copia de la que dirigió a V.S. en 21 del mismo mes el señor prefecto de ese departamento,

(2) Nota adicional: «Dese cuenta al Consejo de Ministros».

(3) AMAE, Correspondencia (Argel), leg. 1818: Despacho del Cónsul general en Argel al ministro de Estado, 4 abril 1851.

(4) Ibidem: Copia de la respuesta del gobernador de Alicante -8 marzo 1851 - a una comunicación del cónsul de España en Argel sobre emigración clandestina. 
relativa al embarque de todos los españoles que arriben a ese país desprovistos de documentos de seguridad, y al dar a V.S. las gracias por su celo y eficacia en participarme aquella disposición, le debo asegurar que adoptaré cuantas medidas juzgue necesarias, para impedir que nuestros patrones conduzcan a esas costas a los que se hallen en aquel caso.

Dios... etc. Alicante 8 de marzo de 1851. JOAQUIN DEL REY (Es copia).

El vicecónsul de S.M., JUAN REY (Es copia). VICENTE DE ZUGASTI.

\section{Satisfacción en Orán (5)}

Viceconsulado de España en Orán.

Con mi despacho de 13 del actual, $n^{\circ} 35$, tuve la honra de participar a V.S. que a consecuencia del considerable número de españoles que llegaban a esta ciudad con pasaportes irregulares, esta autoridad había tomado medidas de rigor contra los que llegasen a este departamento con documentos de esta naturaleza, y que para evitar que en lo sucesivo no se reprodujeran abusos de esta naturaleza, me había dirigido a los gobernadores de Valencia y Alicante, trasladándoles copias de la comunicación que este señor prefecto me habia remitido al efecto.

En su consecuencia, me cabe la satisfacción de anunciar a V.S., que conociendo el señor gobernador de la de Alicante los graves perjuicios que pueden ocasionar semejante abuso, y tomando en consideración las razones que le exponia, me ha remitido la contestación de que es copia el adjunto documento, por la cual dice [quel adoptará cuantas medidas juzgue necesarias para impedir el que nuestros patrones conduzcan a estas costas los que se hallen en tal caso.

Dios... etc. Orán 23 marzo de 1851.

El vicecónsul de S.M., JUAN REY.

Señor Agente Comercial de S.M. en Argel.

III. Dimensiones negativas de la sociedad colonial.

Niña de Polop, victima de estupro en Bona (enero, 1853) (6)

Tribunal de Primera Instancia de Bona (7).

Bona 12 de enero de 1853.

Señor Cónsul:

Un atentado al pudor ha sido cometido a principios de este mes en la persona de una joven española, de ocho años de edad poco más o menos, nombrada Teresa Fuster, hija de Vicente y de Mariana Berenguer, naturales de Polop en la provincia de Alicante.

Siendo la edad de la víctima la circunstancia constitutiva del crimen, agradecería tuviese $\mathrm{V}$. la bondad de hacerme expedir por las autoridades competentes un documento que hiciera constar de un modo legal la fecha precisa del nacimiento de Teresa Fuster.

No ignoro, señor cónsul, que tal vez sería mas regular que este documento me llegase por medio del Ministerio de Negocios Extrangeros, pero un maltés llamado Rosario Galea, acusado del crimen y denunciado por Teresa Fuster, ha sido arrestado hace dos días, y si

(5) Ibidem: Despacho sobre lo mismo del vicecónsul en Orán a su superior en Argel, 23 mayo 1851

(6) AMAE, Correspondencia (Argel), 1818: Comunicación del Tribunal de Primera Instancia de Bona al Cónsul General de España en Argel 12 enero 1853.

(7) Actual Annaba. 
V. no conviene en prestarme su apoyo, su cautividad se hallará indefinidamente prolongada.

Sirvase V. recibir...etc. El procurador imperial, LETOURNEUX.

Sr. Cónsul de España. Argel (8).

\section{Adulteración de vinos de Alicante expedidos a Argelia (agosto, 1855 (9)}

Consulado General de España en Argel.

Excmo. Señor.

Muy señor mío: El vicecónsul de S.M. en Orán me pasó un despacho de 12 de este mes, copia de una comunicación que habia dirigido al señor gobernador civil de la provincia de Alicante, informándole que habiéndose aumentado considerablemente en aquella población, como en toda la Argelia, la importación de vinos de España a consecuencia de la rebaja de los derechos de aduana, y sintiéndose cada vez mas la falta de este líquido por no haber desaparecido aún la enfermedad de la vid que es la que motiva su escasez, i tal circunstancial habia inducido a algunas personas en aquella provincia a aumentar la cantidad o cantidades por medios ilícitos, usando al efecto de materias sumamente perjudiciales a la salud, siendo franceses - según informes recibidos - los que se ocupan en este tráfico, causando graves perjuicios no sólo a la salud pública sino al comercio español. Siendo las primeras victimas los pobres patrones españoles que, habiendo comprado este líquido de buena fe, ven que se rehusa su admisión, prohibiéndoles el desembarque de las partidas que son reconocidas insalubres o falsificadas después de un minucioso análisis.

Después de aprobado el paso dado por el vicecónsul de Orán, previniendo de este hecho al señor gobernador civil de Alicante a fin de que se sirviera tomar las medidas que creyese convenientes para evitar los perjuicios que pudiera acarrear este abuso y el descrédito de un ramo tan importante de nuestro comercio en aquella provincia, me preparaba yo a pasarlo a conocimiento de V.E. cuando a la llegada del correo de Bona de 18 de este mes, recibi carta del vicecónsul de S.M. en aquella ciudad, en que me participa que el coronel comandante de la subdivisión había recibido el 12 del mismo mes, por telégrafo, una orden del gobernador general prohibiendo la introducción de vinos de España en la Argelia sin distinción alguna. Que habiendo llegado en el mismo día a aquel puerto un buque español procedente de Palma con carga de vino, era ejecutada la orden con tal severidad, que por mas que el vino fuese de muy buena calidad, puro y sin falsificación alguna, el patrón no habia podido descargar aún su cargamento a pesar de las razones que el vicecónsul había alegado para hacer comprender a la autoridad la injusticia e ilegalidad de una medida tan grave.

En vista de esto dirigí sin pérdida de tiempo al gobernador general la carta de que es copia el adjunto documento $n^{\circ} 1$, y la escribi en los términos que está redactada, porque antes de escribirla, se me había asegurado verbalmente que la orden del gobernador general habia sido mal entendida. A consecuencia de esta reclamación mia, el gobernador general hizo decir por telégrafo al prefecto de Constantina, que habían sido mal interpretadas las instrucciones.

Por el documento $n^{\circ} 2$, que es copia de la contestación del gobernador general, verá $\checkmark$.E. que la intención de esta autoridad no fue poner obstáculos a la importación de vinos de España, sino que habiendo sabido que se expedían de aquella costa para la Argelia vi-

(8) Traducción oficial del consulado en Argel.

(9) AMAE, Correspondencia, leg. 1818: Despacho del cónsul general en Argel al ministro de Estado. 24 agosto 1855. 
nos falsificados, había debido establecer una eficaz vigilancia a fin de que los líquidos de mala calidad no pudieran entrar en el consumo.

No he podido menos de ponerlo en conocimiento de V.E. para que, si lo creyese conveniente, lo comunique al señor ministro del ramo a que corresponda, a fin de que adopte las medidas conducentes a evitar estos fraudes tan perjudiciales a la buena reputación del comercio español.

Dios... etc. Argel 24 agosto 1855. VICENTE DE ZUGASTI.

Excmo. Señor Primer Secretario del Despacho de Estado. Madrid.

\section{Prófugo alicantino en Argel (Julio, 1856) (10)}

\section{Excmo. Señor:}

Muy Señor mío: Por la adjunta comunicación que tenía preparada para remitir a V.E. al efecto de informarle de cuanto había practicado acerca del mozo Ramón Ponzoda Ponzo$\mathrm{da}-\mathrm{sic}-$, prófugo del actual alistamiento para el reemplazo del Exército, cuyo individuo me habia sido reclamado por el señor gobernador de Alicante, tengo el sentimiento de participar a V.E. que el referido mozo, sin duda mal aconsejado por alguno de sus compatriotas residentes en ésta, se niega ahora a cumplir con la oferta que me habia hecho.

Esta circunstancia, Excmo. Señor, me impone el deber de elevarlo a su superior conocimiento, participándole al propio tiempo que con igual fecha doy conocimiento de ello al señor gobernador de la indicada ciudad, para que se sirva adoptar aquellas medidas que crea conducentes con respecto al individuo de que se trata.

Dios... etc. Argel 11 julio 1856.

B.I.m. de V.E., VICENTE DE ZUGASTI.

Excmo. Señor Primer Secretario del Despacho de Estado. Madrid.

\section{Nutrida inmigración clandestina. Situación \\ de los colonos españoles (febrero, 1860) (11)}

\section{Consulado General de España en Argel. \\ Excmo. Señor.}

Muy Señor mío: Adjunta tengo el honor de pasar a manos de V.E. la relación de españoles residentes en esta colonia (12), que se sirve pedirme por la Real orden circular de 13 de enero último, y al verificarlo debo manifestarle que no sin mucho trabajo he podido reunir los datos necesarios para formarla, aunque menos completa que lo que V.E. deseaba por no existir en la cancilleria de este Consulado general mas que un principio de registro de matriculados a causa de no llenar este deber los españoles, por la tendencia continua que tienen a sustraerse a la jurisdicción consular siempre que ésta no les es necesaria, y a eludir las órdenes del Gobierno, y lo pueden [hacer] muy fácilmente no teniendo los cónsules medio alguno de acción sobre ellos, al par que las autoridades locales, para incitarles a establecerse en la colonia y a refundirse en la nacionalidad francesa, lejos de prestar a los agentes extrangeros el necesario apoyo, están auxiliando sordamente su desobediencia.

Aunque no existiesen estas circunstancias y otras muchas que sería largo referir, y no son del caso en esta comunicación, sería casi imposible llevar en orden un libro de matri-

(10) Ibidem, ibd. 11 julio 1856.

(11) AMAE, Correspondencia (Argel), leg 1819: Despacho del cónsul general en Argel al ministro de Estado, 20 febrero 1860.

(12) No consta en el expediente. 
culados en un país en que la población española es tan numerosa y esencialmente móvil, al par que muy esparcida tanto en el territorio civil como en el militar; en que la autoridad apenas está constituida, y por tanto no es hacedero tener una cuenta exacta de los muchos españoles que recorren sin cesar, unos comerciantes y otros trabajando en clase de jornaleros do quiera que encuentran ocupación, un pais tan vasto como de población mezclada.

He tenido que valerme de la estadistica formada por las autoridades civiles, por los cónsules y vicecónsules, y de los datos que particularmente ha podido adquirir este Consulado general. La falta de agente nacional en la capital hace que los de la provincia de Constantina sean menos completos que los de Orán y Argel.

A excepción de don Salvador Coll, que en las inmediaciones de Bona posee 10.000 hectáreas de tierras, no hay en Argelia ningún español notable por su riqueza y posición. Aún en esta capital, salvo tres o cuatro comerciantes, todos son tenderos, jornaleros o pescadores. En la provincia bastantes poseen pequeñas concesiones y se dedican a la agricultura. Algunos en las inmediaciones a la capital han reunido algún dinero, ocupándose con provecho en la horticultura.

Respecto a los emigrados $y$ desertores, es imposible prefijar a V.E. su número ni aún aproximado, pues el Consulado es el último punto donde se darian a conocer. La autoridad local que acoge a todos los extranjeros que se presentan sin informarse de sus antecedentes, y aunque vengan desprovistos de papeles, les incluye con los demás en su estadística. Además hay numerosísimos españoles que sin tener hecha ninguna [infracción en nuestro país], han venido a Argelia enteramente desprovistos de documentos, unos por desidia y otros porque saben que las autoridades francesas no ponen en ello ningún reparo, de modo que no es posible distinguir unos de otros.

Dios... etc. Argel 20 de febrero de 1860. VICENTE DE ZUGASTI.

Excmo. Señor Ministro de Estado. Madrid.

VII. Inseguridad en la colonia. Minero natural de Elche secuestrado por los cabileños a caballo de la frontera con Túnez (Enero 1861) (13)

Viceconsulado de España en La Calle.

El 20 del corriente tres jornaleros empleados en la mina de Oun- te Boul fueron capturados por los árabes de la parte de la frontera de Túnez: Como se presumía que entre ellos había un español, escribi inmediatamente al director de aquel establecimiento, el cual me mandó ayer uno de sus empleados para decirme que, en efecto, entre los tres capturados se hallaba el nombrado José Navarro, de 29 años poco más o menos, nativo de Elche, hijo de Jaime y de Margarita Gómez; Que habían mandado un árabe, también empleado en la mina, para informarse de la suerte de estos infelices, y que les halló en una tribu, encadenados y con poca voluntad de darles la libertad. Lo que ha obligado al señor comandante superior a dar parte por telégrafo al señor gobernador general para que dé las órdenes que sean oportunas para obtener la restitución de los capturados, lo que a mi modo de ver será algo difícil si los árabes de la tribu en donde están rehusan a ello, porque no están sometidos al Gobierno francés y menos al de Túnez, y puede muy bien que la tropa si viene para perseguirles no pueda alcanzarles.

Verificación hecha de todos los pasaportes que existen en este viceconsulado, no he hallado el del referido Navarro, lo que me hace creer que a su llegada aqui no lo había depositado en la policía.

(13) AMAE, Correspondencia (Argel), leg 1818. Notificación del vicecónsul de España en La Calle a su superior en Argel, 26 enero, 1861. 
No faltaré en dar parte a V.S. de todo cuanto ocurra hasta el correo próximo para su inteligencia y gobierno, a fin de darme las instrucciones que crea necesarias por si Navarro no pudiera obtener la libertad sin el rescate.

Dios... etc. La Calle 25 enero 1861. El viceconsul GHEBARDI Señor Consul General de España en Argel.

VIII. Persiste la inmigración clandestina. Cierto laud de Santapola intruduce en el puerto argelino de Ténes a un grupo de emigrantes procedente de Altea (julio, 1862) (14)

Excmo. Señor.

Muy Señor mio:

Tengo el honor de remitir a V.E. copia del oficio que el viceconsul de S.M. en Ténes me dirije detallando lo ocurrido en dicho puerto el 25 de junio último al desembarcar el patrón Mulet clandesfinamente varios pasageros.

El laud «Santa Isabel», ful. 32 de la $1^{\text {a }}$ lista de embarcaciones de Santapola, llegó a este puerto en 27 de junio por la noche. El patrón que lo manda Juan Mulet y Boronat, natural de Calpe, fol. 985 de la lista de hábiles, matrícula de 1847, se presentó en este consulado el 28 por la mañana, e interpelado que fue, dijo no traer a bordo desde Altea mas que doce pasageros y sostuvo no haber desembarcado clandestinamente ninguno en Ténes.

En averiguración de los hechos que se me habian denunciado, ordené la presentación de la tripulación y pasageros. En sus declaraciones vi claramente traían estudiado lo que debían decir. Efectivamente, el señor vicecónsul, llamado al puerto para resolver un asunto del servicio, se encontró con los que acababan de salir de la cancillería, y agenos al recelo, alli hablaban. Pudo oir como el capitán felicitaba y daba gracias a su gente por no haberle denunciado. Entonces reconvino al poco escrupuloso patrón y a sus marineros por haber faltado a la verdad en sus declaraciones juradas, y consignó al patrón Mulet por 24 horas en su buque en clase de arresto por la excitación a la desobediencia que con sus palabras acababa de hacer.

Los cinco individuos desembarcados clandestinamente fueron habidos por la policía, y como pretendieron tener sus pasaportes en esta (cancillería), no les arrestaron. Adjunto el despacho en que se solicitaban informes, anejo $n^{\circ} 2$. Cuando llegó la orden de conducirles a Argel para tomarles declaración, ya habían desaparecido.

Los hechos narrados prueban de modo evidente la falta del patrón Mulet. Si por ella obtiene un castigo ejemplar, [se] corregirá en parte los abusos que en este sentido se cometen, por desgracia con demasiada frecuencia, neutralizando al mismo tiempo la corriente de emigración e impidiendo los embarques clandestinos que, paralizando la acción de la justicia, alienta a los criminales en su depravada senda.

Todo lo que digo a V.E. para que, si lo cree oportuno, lo traslade a quien corresponda para los fines a que haya lugar.

Dios... etc. Arget 5 julio 1862. VICENTE DE ZUGASTI.

Excmo. Señor Primer Secretario de Estado. Madrid.

IX. Emigración política. Un presunto agente carlista (Julio, 1872) (15)

Excmo. Señor.

Muy Señor mío: Por conducto fidedigno se me aseguró ayer que en Orán se hallaba, re-

(14) Ibidem: Despacho del cónsul general en Argel al ministro de Estado, 5 julio 1862.

(15) AMAE, Correspondencia (Orán), leg 1998: Despacho del cónsul en Orán al ministro de Estado, 8 julio 1872. 
cién llegado de Alicante, un rico hacendado, de Benisa, llamado don José Feliu. Dícinme que viene con designios carlistas y que, al efecto, se dispone a hacer una excursión para entenderse y concertarse con sus correligionarios de Arzew y Mostaganem.

Vi ayer a nuestro agente consular del primero de estos puntos, e inmediatamente envié al de Mostaganem orden de trasladarse a Orán, a donde llegó esta mañana.

Uno y otro me han dado la seguridad de que todo está tranquilo en sus respectivos distritos. Ambos llevan a ellos las instrucciones mas detalladas y las órdenes más categóricas respecto a lo que, según las circunstancias, convenga o se deba hacer.

Esta tentativa descubierta a tiempo, quedará abortada como las anteriores.

Dios... etc. Orán 8 julio 1872.

Excmo. Señor b. la m. de V.E. su mas atento [y] seguro servidor A. DE BURGOS.

Excmo. Señor Ministro de Estado. Madrid.

$X$. El consul en Orán remite a Alicante un presidiario, refugiado en Argelia tras los sucesos cantonales de Cartagena, y a dos prófugos (Noviembre, 1874) (16)

Excmo. Señor.

Muy Señor mio: Tengo la honra de anunciar a V.E. que por el vapor español «Non Plus Ultra», capitán don José de Mesa, he remitido el dia 7 a disposición del gobernador civil de Alicante, el individuo llamado Blas Ramón Quiles, natural de Elche, fugado del penal de Cartagena y llegado a ésta con la fragata «Numancia».

El mismo dia y por el propio conducto remití también a disposición de aquella autoridad [a] dos prófugos de quintas. Dentro de dos dias será igualmente enviado a Alicante Pedro Ayala, natural de Murcia, indocumentado que declara haber estado en Cartagena y tomado parte en el movimiento insurreccional.

Dios... etc. Orán 10 de noviembre de 1874.

Excmo. Señor b.l.m. de V.E. en su mas atento y seguro servidor, TOMAS ORTUÑO. Excmo. Señor Ministro de Estado. Madrid.

(16) Ibidem: Despacho del cónsul en Orán al ministro de Estado, 10 noviembre 1874. 